\title{
Evaluation of models for prediction of the energy value of diets for growing cattle from the chemical composition of feeds ${ }^{1}$
}

\author{
Cláudia Batista Sampaio², Edenio Detmann ${ }^{3}$, Sebastião de Campos Valadares Filho ${ }^{3}$, \\ Augusto César de Queiroz ${ }^{3}$, Tiago Neves Pereira Valente ${ }^{2}$, Robério Rodrigues Silva ${ }^{4}$, \\ Marjorrie Augusto de Souza ${ }^{2}$, Viviane Aparecida Carli Costa ${ }^{5}$
}

\author{
${ }^{1}$ Funded by FAPEMIG (PPM), CNPq and INCT-Ciência Animal. \\ 2 Programa de Pós-Graduação em Zootecnia, Universidade Federal de Viçosa, Viçosa-MG, Brazil. \\ ${ }^{3}$ Departamento de Zootecnia, Universidade Federal de Viçosa, Viçosa-MG. Researcher from CNPq and INCT-Ciência Animal. \\ ${ }^{4}$ Departamento de Estudos Básicos e Instrumentais, Universidade Estadual do Sudoeste da Bahia, Itapeting-BA, Brazil. \\ ${ }^{5}$ Centro de Ciências e Tecnologias Agropecuárias, Universidade Estadual do Norte Fluminense, Campos dos Goytacazes-RJ, Brazil.
}

\begin{abstract}
The objective of this study was to estimate and evaluate the contents of apparently digestible fractions of crude protein, ether extract and non-fibrous carbohydrates, the digestible fraction of the neutral detergent fiber and the content of total digestible nutrients (TDN) from the chemical composition of feeds in growing cattle fed different diets. Fourteen F1 Red Angus $\times$ Nellore young bulls with average age and weight of 12 months and $287 \pm 36 \mathrm{~kg}$ were used. Animals were fed elephant grass silage, corn silage or signal grass hay, with or without supplementation of $200 \mathrm{~g}$ concentrate per $\mathrm{kg}$ of the total diet. The experiment consisted of two 13-days periods, in which the concentrate supplementation was crossed over animals. The values of digestible fractions and the TDN content observed were obtained based on total collection of feces. Several sub-models applied to the different digestible fractions were assessed and discussed. Estimates of the TDN content in the diet were produced from the combination of sub-models applied to the individual digestible fractions. The TDN content was more efficiently predicted from the sub-models proposed by Detmann et al. (2010) when biological procedures for the estimation of the undegradable fraction of the protein and the potentially degradable fraction of the neutral detergent fiber were considered.
\end{abstract}

Key Words: apparently digestible fractions, feed analysis, total digestible nutrients

\section{Introduction}

The estimation of digestibility coefficients constitutes a basic aspect to quantify the energy value of feeds or diets, remarkably via total digestible nutrients (TDN), allowing the adequate balancing of diets that meet the requirements of animal for maintenance and production (Detmann et al., 2010a).

Estimates of digestibility coefficients with cattle obtained in vivo must be considered more exact; however, the need for utilizing experimental animals, in addition to the great quantity of feeds and longer time, makes this process cumbersome and laborious.

As an alternative to avoid such limitations, methods for prediction of the digestible fractions of diets for ruminants utilizing the chemical composition of feeds have been developed by Conrad et al. (1984) and Weiss et al. (1992), whose fundaments were used to set up the systems of energy prediction proposed by the NRC (2001) for temperate conditions, and more recently for tropical conditions, by Detmann et al. (2008a; 2010a).
These systems are based on summative equation systems, in which for each group of chemical compounds with potential for energy contribution (crude protein - CP; ether extract - EE; non-fibrous carbohydrates - NFC; and neutral detergent fiber - NDF), an equation is used for the obtainment of estimates of the truly digestible fractions, with subsequent corrections concerning the fecal metabolic losses and intake level.

However, comparative studies between the prediction systems previously mentioned are still scarce in the literature. Therefore, the objective of this study was to compare the estimates of digestible fractions and TDN content obtained based on the chemical composition of feeds using the models proposed by the NRC (2001) and by Detmann et al. (2010a) in growing cattle fed different diets.

\section{Material and Methods}

The experiment was carried out in the Departamento de Zootecnia of Universidade Federal de Viçosa, located in Viçosa, Minas Gerais, Brazil. 
Fourteen F1 Red Angus $\times$ Nellore young bulls with average age and weight of 12 months and $287 \pm 36 \mathrm{~kg}$ were used. The basal forage was constituted of elephant grass (Pennisetum purpureum cv Cameroon) silage for six animals, corn (Zea mays) silage for six animals and signal grass (Brachiaria decumbens) hay for two animals. The experiment was composed of two 13-day periods; the first five days were intended for adaptations of animals. Prior to the beginning of the experiment, animals were adapted to the facilities and experimental conditions for 14 days.

In the first experimental period, half of the animals in each forage was supplemented with $200 \mathrm{~g}$ concentrate per $\mathrm{kg}$ of total dry matter (DM) of the diet. In the second period, the supplementation was crossed over animals. The concentrate was composed of corn meal, soybean meal and a mineral mix, balanced to present approximately $300 \mathrm{~g}$ $\mathrm{CP} / \mathrm{kg} \mathrm{DM}$.

On the eighth, tenth and thirteenth days, total collection of feces was conducted, beginning at $7 \mathrm{~h} 00$ and extending to the period of 24 hours. Feces were collected during spontaneous defecation and conditioned in plastic containers kept under shade. Subsequently, samples were homogenized and quantified; an aliquot of $100 \mathrm{~g} / \mathrm{kg}$ of the total was taken and frozen $\left(-20^{\circ} \mathrm{C}\right)$ for further analyses.

For the quantification of voluntary intake, feeds supplied between the sixth and the twelfth days and orts obtained between the seventh and thirteenth days of each experimental period were considered. Samples of feed and orts were composed per animal and period and frozen $\left(-20^{\circ} \mathrm{C}\right)$.

After thawing, samples of feeds, orts and feces were oven-dried $\left(60^{\circ} \mathrm{C}\right)$ and processed in a knife mill (1 and $2 \mathrm{~mm}$ ). Samples processed at $1 \mathrm{~mm}$ screen sieve were analyzed regarding $\mathrm{DM}, \mathrm{EE}$, organic matter $(\mathrm{OM})$, acid detergent fiber (ADF) and lignin $\left(\mathrm{H}_{2} \mathrm{SO}_{4}, 720 \mathrm{~g} / \mathrm{kg}\right)$, according to methods described by Silva \& Queiroz (2002). The contents of NDF were obtained according to Mertens (2002), utilizing a thermo-stable $\alpha$-amylase and omitting the utilization of sodium sulfite. The NDF corrections concerning ash and protein were conducted according to Mertens (2002) and Licitra et al. (1996), respectively. The contents of neutral detergent insoluble protein (NDIP) and acid detergent insoluble protein (ADIP) were estimated by the Kjeldahl method after extraction with the respective detergents (Licitra et al., 1996). The chemical composition of forages and concentrate is presented in Table 1 and the observed values of digestible fractions are presented in Table 2.

The NFC contents were obtained according to Detmann \& Valadares Filho (2010):

$N F C=O M-(E E+N D F a p+C P)$

where: NFC, non-fiber carbohydrates content; OM, organic matter content; EE, ether extract content; NDFap, content of

Table 1 - Average contents of dry matter (DM), organic matter $(\mathrm{OM})$, crude protein $(\mathrm{CP})$, ether extract $(\mathrm{EE})$, neutral detergent fiber corrected for ash and protein (NDFap), non-fibrous carbohydrates (NFC), lignin, neutral detergent insoluble protein (NDIP), acid detergent insoluble protein (ADIP) and undegradable neutral detergent insoluble protein (UNDIP) in forages and concentrate

\begin{tabular}{lcccc}
\hline & \multicolumn{3}{c}{ Forage } & \\
\cline { 2 - 4 } Item & $\begin{array}{c}\text { Corn } \\
\text { silage }\end{array}$ & $\begin{array}{c}\text { Elephant grass } \\
\text { silage }\end{array}$ & $\begin{array}{c}\text { Brachiaria } \\
\text { hay }\end{array}$ & Concentrate \\
\hline DM, g/kg as fed & 286 & 312 & 927 & 881 \\
OM, g/kg DM & 958 & 966 & 958 & 949 \\
CP, g/kg DM & 60 & 38 & 44 & 294 \\
EE, g/kg DM & 32 & 11 & 11 & 14 \\
NDFap, g/kg DM & 501 & 740 & 755 & 241 \\
NFC, g/kg DM & 364 & 176 & 147 & 399 \\
Lignin, g/kg DM & 41 & 96 & 92 & 22 \\
iNDF, g/kg DM & 142 & 391 & 281 & 27 \\
NDIP, g/kg DM & 11 & 13 & 18 & 67 \\
ADIP, g/kg DM & 8 & 9 & 12 & 12 \\
UNDIP, g/kg DM & 9 & 8 & 11 & 10 \\
NDIP, g/kg CP & 177 & 359 & 409 & 230 \\
ADIP, g/kg CP & 128 & 262 & 279 & 8 \\
UNDIP, g/kg CP & 146 & 196 & 243 & 34 \\
\hline
\end{tabular}

Table 2 - Average observed contents of apparently digestible crude protein, ether extract, and non-fibrous carbohydrates, digestible neutral detergent fiber corrected for ash and protein and total digestible nutrients in the diet according to forage and concentrate level

\begin{tabular}{|c|c|c|c|c|c|c|}
\hline \multirow{3}{*}{ Item } & \multicolumn{6}{|c|}{ Forage $^{1}$} \\
\hline & \multicolumn{2}{|c|}{ Corn silage } & \multicolumn{2}{|c|}{ Elephant grass silage } & \multicolumn{2}{|c|}{ Signal grass hay } \\
\hline & 0 & 200 & 0 & 200 & 0 & 200 \\
\hline Apparent digestibility crude protein, g/kg DM & $23 \pm 5.5$ & $84 \pm 2.4$ & $2 \pm 3.2$ & $69 \pm 1.5$ & $10 \pm 0.7$ & $63 \pm 4.0$ \\
\hline Apparent digestibility ether extract, $\mathrm{g} / \mathrm{kg}$ DM & $32 \pm 0.8$ & $25 \pm 1.4$ & $7 \pm 1.6$ & $8 \pm 0.5$ & $8 \pm 1.2$ & $9 \pm 0.4$ \\
\hline Non-fibrous carbohydrates, $\mathrm{g} / \mathrm{kg} \mathrm{DM}$ & $220 \pm 5.9$ & $244 \pm 1.9$ & $45 \pm 13.6$ & $114 \pm 11.0$ & $69 \pm 10.4$ & $121 \pm 7.1$ \\
\hline $\begin{array}{l}\text { Digestible neutral detergent fiber corrected for } \\
\text { ash and protein, g/kg DM }\end{array}$ & $295 \pm 21.9$ & $265 \pm 11.8$ & $371 \pm 19.4$ & $319 \pm 16.6$ & $514 \pm 27.0$ & $438 \pm 13.3$ \\
\hline Total digestible nutrients, $\mathrm{g} / \mathrm{kg} \mathrm{DM}$ & $611 \pm 27.0$ & $653 \pm 20.6$ & $435 \pm 25.5$ & $523 \pm 21.8$ & $613 \pm 13.3$ & $645 \pm 9.5$ \\
\hline
\end{tabular}

$\mathrm{DM}=$ dry matter; NDFap = neutral detergent fiber corrected for ash and protein.

${ }^{1}$ Mean \pm standard error. 
neutral detergent fiber corrected for ash and protein; and CP, crude protein content. All the terms are expressed as $\mathrm{g} / \mathrm{kg}$ DM.

For the quantification of the indigestible NDF (iNDF) contents, aliquots of samples processed at $2 \mathrm{~mm}$ screen sieve were used. Samples were conditioned in triplicate in non-woven textile bags $\left(100 \mathrm{~g} / \mathrm{m}^{2} ; 4 \times 5 \mathrm{~cm}\right)$, keeping the ratio of $25 \mathrm{mg} \mathrm{DM} / \mathrm{cm}^{2}$ surface. The bags were then heatsealed and incubated for 264 hours (Casali et al., 2008) in the rumen of an adult cattle fed a diet based on elephant grass silage and concentrate (80:20).

After incubation, bags were removed, washed in tap water until their complete clearing and oven-dried $\left(60^{\circ} \mathrm{C}\right)$. Afterwards, bags were subjected to extraction with neutral detergent fiber, in a fiber analyzer (Ankom $220^{\circledR} ; 100^{\circ} \mathrm{C} / 1$ hour). After the extraction, bags were washed with hot distilled water and acetone, then dried in a ventilated oven $\left(60^{\circ} \mathrm{C} / 72\right.$ hours $)$ and a non-ventilated oven $\left(105^{\circ} \mathrm{C} / 1\right.$ hour), conditioned in dissecator and weighed. The residue obtained was considered the iNDF. The contents of undegradable neutral detergent insoluble protein (UNDIP) were estimated from the residual protein of the iNDF (Clipes et al., 2010a).

The estimation of the dietary contents of the digestible fractions of the different components according to the NRC (2001) was based on the following sub-models:

$t d N F C=0.98 \times N F C$

$t d E E=E E-10$

$t d C P=C P \times \exp \left[-1.2 \times\left(\frac{A D I P}{C P}\right)\right.$ (forages)

$t d C P=C P \times\left[1-0.4 \times\left(\frac{A D I P}{C P}\right)\right] \quad($ concentrate $)$

$d N D F=0.75 \times\left\{(\right.$ NDFap $\left.-L) \times\left[1-\left(\frac{L}{\text { NDFap }}\right)^{0.667}\right]\right\}$

where: tdNFC, truly digestible NFC (g/kg DM); tdEE, truly digestible $\mathrm{EE}(\mathrm{g} / \mathrm{kg} \mathrm{DM})$; tdCP, truly digestible $\mathrm{CP}(\mathrm{g} / \mathrm{kg}$ $\mathrm{DM}$ ); dNDF, digestible NDF (g/kg DM); L, diet content of lignin $(\mathrm{g} / \mathrm{kg} \mathrm{DM}) ; 0.667$, lignin constraint factor on NDF ruminal degradation; 0.75 , digestibility coefficient of the potentially degradable fraction of the NDF; the other terms have been previously defined $(\mathrm{g} / \mathrm{kg} \mathrm{DM})$.

The NDF contents utilized in equation (6) do not originally comprehend corrections for ash (NRC, 2001). However, this modification was incorporated because the mineral content of the NDF presents null energy contribution, which promotes better aggregation to the aim of estimating the energy content (Detmann et al., 2007; Detmann \& Valadares Filho, 2010).

The truly digestible fractions of the non-fibrous components provided by the sub-model adopted by the NRC (2001) were converted into apparently digestible fractions based on the metabolic fecal contributions described by Weiss et al. (1992) (6.2; 27 and $31 \mathrm{~g} / \mathrm{kg}$ for EE, NFC and $\mathrm{CP}$, respectively). The objective of this conversion was to make possible the direct comparison with the observed values of each fraction.

The sub-models for the estimation of the truly digestible fractions of EE and NFC proposed by Detmann et al. (2010a) are:

$t d E E=0.86 \times E E$

$t d N F C=0.95 \times N F C$

where all the terms have been previously defined.

The apparently digestible fractions were estimated from the subtraction of metabolic fecal fraction, considering growing and finishing cattle fed ad libitum (production level of intake), which take on values of 1.8 and $51.1 \mathrm{~g} / \mathrm{kg}$ for EE and NFC, respectively (Detmann et al., 2010a).

The sub-model proposed by Detmann et al. (2007; 2008a; 2010a) for the estimation of the digestible fraction of NDF was based on the fractionation of this component into its potentially digestible and indigestible fractions, as demonstrated below:

$d N D F=D \times p d N D F$

$d N D F=D \times(N D F a p-i N D F)$

where: pdNDF, potentially digestible NDF (g/kg DM); D, digestibility coefficient of the pdNDF; the other terms have been previously defined ( $\mathrm{g} / \mathrm{kg} \mathrm{DM})$.

In this study, the iDNF fraction (and consequently, the pdNDF) was estimated through a biological procedure of in situ rumen incubation, as previously described; the estimates obtained were directly input into the model described in (10).

The pdNDF and iNDF fractions constitute complementary asymptotic biological concepts (Detmann, 2010) whose accurate punctual evaluation is only obtained by means of long-term biological assays (rumen incubations) in times equal or superior to 240 hours (Casali et al., 2008; Valente, 2010). In this context, estimates of the pdNDF fraction could be obtained by chemical approximation to make the evaluation process faster and independent of the availability of fistulated animals (Detmann et al., 2007).

Considering this, the pdNDF fraction was estimated by chemical approach, which converts the model described in (10) into the equation (Detmann et al., 2007; 2010a):

$d N D F=0.75 \times\left\{(\right.$ NDFap $\left.-L) \times\left[1-\left(\frac{L}{N D F a p}\right)^{0.85}\right]\right\}$

where: 0.85 , lignin constraint factor on NDF ruminal degradation.

Both for the biological and chemical approaches, three estimates of the digestibility coefficient of the pdNDF were 
utilized: $0.67 ; 0.84$ and 0.76 , which represent, respectively, the estimates proposed for growing/finishing cattle, lactating cows (Detmann et al., 2007) and their average, respectively. This can be justified by the arguments presented by Detmann et al. (2010a), which indicated that some refinement still needs to be done on the estimates proposed. Thus, the utilization of various coefficients aims at the evaluation of the influence of this parameter on the accuracy of the dNDF estimates.

The first sub-model utilized for the evaluation of the digestible fraction of the $\mathrm{CP}$ was based on the same presuppositions adopted for EE and NFC (Detmann et al., 2010a), according to the equation:

$t d C P=0.78 \times C P$

In this single-compartment sub-model, the $\mathrm{CP}$ is evaluated as a homogeneous nutritional entity (Detmann et al., 2010a). However, under tropical conditions, there is an intense and complex association of the nitrogenous compounds to the insoluble fibrous fraction, which may compromise the assumption of homogeneity of the digestion process of the CP (Detmann et al., 2008b).

This way, a two-compartment sub-model in which the utilization of the $\mathrm{CP}$ in the gastrointestinal tract of a ruminant is assumed as heterogeneous was built based on the approaches (Detmann et al., 2008b):

$C C C P \cong C P-C W C P \Rightarrow C C C P \cong C P-N D I P$

$C W C P \cong N D I P$

where: $\mathrm{CCCP}$, cell content $\mathrm{CP}$; $\mathrm{CWCP}$, cell wall $\mathrm{CP}$; and NDIP, neutral detergent insoluble protein; all terms are expressed as $\mathrm{g} / \mathrm{kg}$ of DM.

According to derivations of Detmann et al. (2008b; 2010a), the CCCP presents digestive pattern similar to the other non-fibrous components (EE and NFC), whereas, by assumption, the utilization of CWCP would be similar to that observed for the NDF.

Therefore, the tdCP fraction would be expressed, considering the approaches represented below:

$t d C P=t D_{C C C P} \times C C C P+D_{p d C W C P} \times p d C W C P$

$t d C P=t D_{C C C P} \times(C P-N D I P)+D_{p d C W C P} \times(N D I P-U N D I P)(16)$, where: tDCCCP, true digestibility coefficient of the CCCP; pdCWCP, potentially digestible CWCP (g/kg DM); $\mathrm{D}_{\mathrm{pdCWCP}}$ digestibility coefficient of the pdCWCP; UNDIP, undegradable neutral detergent insoluble protein $(\mathrm{g} / \mathrm{kg} \mathrm{DM})$; the other terms have been previously defined ( $\mathrm{g} / \mathrm{kg} \mathrm{DM})$.

In this case, $0.98 \mathrm{~g} / \mathrm{g}$ was assumed as an estimate for the true digestibility coefficient of the CCCP $(\mathrm{g} / \mathrm{g})$ (Van Soest, 1994; Detmann et al., 2006a; 2008b) and estimates similar to those utilized for the fibrous fraction of the feedstuff/diet were assumed as digestibility coefficient of the pdCWCP.
Therefore, the three estimates of digestibility coefficient of the pdNDF previously mentioned were also evaluated for the estimation of the tdCP in the two-compartment approach.

The UNDIP is analytically defined as the approach to the parametric value of the undegradable protein of the cell wall, consisting of the evaluation of the residual $\mathrm{CP}$ of the iNDF (Detmann et al., 2010a). Thus, the UNDIP values were directly estimated and input into the equation (16).

However, this analytic approach can constitute a constraint in some situations due to unavailability of fistulated animals. This way, the UNDIP values can be obtained by chemical approach from the concentration of ADIP (Detmann et al., 2010b), by converting the equation (16) into:

$$
\begin{aligned}
& t d C P=0.98 \times(C P-N D I P)+D_{p d C W C P} \times\{N D I P \times \\
& \left.\left[1-e^{-(0.8188+0.11676 \times A D I P)}\right]\right\}
\end{aligned}
$$

where all terms are expressed as $\mathrm{g} / \mathrm{kg} \mathrm{DM}$.

The estimates of tdCP were converted into apparently digestible fractions by subtracting the metabolic fecal contribution of the $\mathrm{CP}$ concerning growing/finishing beef cattle under unrestricted feeding $(16.1 \mathrm{~g} / \mathrm{kg}$; Detmann et al., 2010a).

The TDN contents were obtained by the sum of the estimates produced by each sub-model for each digestible fraction from the equation:

$T D N=a d C P+a d N F C+d N D F+2.25 \times a d E E$

where: TDN, TDN content ( $\mathrm{g} / \mathrm{kg} \mathrm{DM})$; adCP, adNFC and adEE: apparently digestible fractions of CP, NFC and EE, respectively $(\mathrm{g} / \mathrm{kg} \mathrm{DM})$; dNDF, digestible fraction of the $\mathrm{NDF}$ (g/kg DM); and 2.25, Atwater's constant for equating lipids to carbohydrates.

It must be emphasized that no correction regarding the level of intake was conducted for the TDN contents predicted by the sub-models adopted by the NRC (2001), once the estimated values were below the minimum value defined for the utilization of correction $(600 \mathrm{~g} / \mathrm{kg} \mathrm{DM})$.

The efficiency of prediction of sub-models for apparently digestible fractions and TDN contents was assessed in relation to the values observed in vivo through the estimate of the mean square of prediction error and its components (Kobayashi \& Salam, 2000):

$$
\begin{aligned}
& M S P E=S B+S D S D+L C S=\frac{1}{n} \sum_{i=1}^{n}\left(x_{i}-y_{i}\right)^{2} \\
& S B=(\bar{x}-\bar{y})^{2} \\
& S D S D=\left(s_{x}-s_{y}\right)^{2} \\
& L C S=2 s_{x} s_{y}(1-r)
\end{aligned}
$$

where: $\mathrm{x}$, predicted values; $\mathrm{y}$, observed values; MSPE, mean squared prediction error; SB, squared bias; SDSD, 
difference in the magnitude of fluctuation between predicted and observed values; LCS, the lack of positive correlation between predicted and observed values weighted by the standard deviations; $\mathrm{s}_{\mathrm{x}}$ and $\mathrm{s}_{\mathrm{y}}$, standard deviations for predicted and observed values, respectively; and r, Pearson's linear correlation between predicted and observed values.

It must be brought into evidence that because this is an evaluation of the prediction error, the total of observations (n) was employed as divisor for all the calculations of variances and covariances (Kobayashi \& Salam, 2000).

The efficiency of prediction was also evaluated by means of the estimate of the concordance correlation coefficient (CCC) or reproducibility index, estimated according to Tedeschi (2006).

Because of the great number of sub-models evaluated for adCP and dNDF, which is due to combinations of methods (biological or chemical approach) and of different estimates of digestibility coefficients, hierarchical clustering analysis was conducted (Cruz \& Regazzi, 2002) for evaluation of the similarity between sub-models and TDN contents. Estimates of MSPE, SB, SDSD, LCS and CCC were utilized, by employing the Euclidian distance as dissimilarity measurement.

\section{Results and Discussion}

The adEE values predicted by the sub-model presented by Detmann et al. (2010a) were more accurate in comparison with the sub-model adopted by the NRC (2001). This pattern is made clear by the lower mean prediction error and, consequently, by the lower estimate of the component SB (Table 3). On the other hand, the sub-models were equally precise because no remarkable difference could be verified on components SDSD and LCS, which enable the evaluation of how the sub-models are capable of simulating the intensity and direction of the random fluctuation of the data observed in relation to the arithmetic mean of the evaluated sample, respectively. Thus, the best estimate of CCC presented by the sub-model adopted by Detmann et al. (2010a) is exclusively due to its better accuracy (Table 3), once this descriptive statistics approaches, simultaneously, aspects of accuracy and precision of the evaluated model (Tedeschi, 2006). This greater adequacy is reinforced by the behavior of the ordered pairs (Figure 1).

The main difference between the sub-model applied to the prediction of the adEE proposed by Detmann et al. (2010a) and the one adopted by the NRC (2001) lies in the method of estimation of the truly digestible fraction of the EE.

For the sub-model adopted by the NRC (2001), the average contents of non-fatty EE verified in diets for ruminants would be of approximately $10 \mathrm{~g} / \mathrm{kg} \mathrm{DM}$ (Weiss et al., 1992). This estimate would allow the estimation of the content of fatty acids in the diet through a simple subtraction of constant, by presupposing, in addition, true digestibility of $1.0 \mathrm{~g} / \mathrm{g}$ for the dietary fatty acids (Weiss et al., 1992).

Alternatively, in the sub-model proposed by Detmann et al. (2010a), the estimation process of the content of true digestible $\mathrm{EE}$ is given by the multiplicative coefficient which represents the true digestibility coefficient of EE (Equation 7), which is estimated under the presupposition that EE meets the premises of the concept of nutritional entity concept (Lucas \& Smart, 1959; Detmann et al., 2006b).

The adoption of a constant subtraction for the estimation of the truly digestible EE content implies that every source of EE, except for oils and fats, presents an absolute common fraction of compounds that can not be used in the animal metabolism, which would represent the complement of the amount of fatty acids present in the feed. Such fraction is usually composed of waxes, carotenoids and other indigestible compounds (Detmann et al., 2006b). However, the wide variability in the relation between the contents of fatty acids and non-fatty EE among feeds may

Table 3 - Means ( $\mathrm{g} / \mathrm{kg}$ dry matter) and descriptive statistics of the relation between observed and predicted values of the diet contents of apparently digestible ether extract and of apparently digestible non-fibrous carbohydrates

\begin{tabular}{|c|c|c|c|c|c|c|c|c|c|}
\hline Model & Mean & $\mathrm{s}$ & MPE & MSPE & SB & SDSD & LCS & $\mathrm{r}$ & $\mathrm{CCC}$ \\
\hline \multicolumn{10}{|c|}{ Apparently digestible ether extract } \\
\hline Observed & 17.2 & 10.9 & - & - & - & - & - & - & - \\
\hline NRC (2001) & 3.5 & 9.4 & -13.7 & 195.2 & 187.7 & 2.1 & 5.3 & 0.972 & 0.505 \\
\hline Detmann et al. (2010a) & 15.1 & 8.1 & -2.0 & 16.4 & 4.3 & 7.4 & 4.7 & 0.973 & 0.911 \\
\hline \multicolumn{10}{|c|}{ Apparently digestible non-fibrous carbohydrates } \\
\hline Observed & 147.5 & 81.7 & - & - & - & - & - & - & - \\
\hline NRC (2001) & 231.2 & 89.7 & 83.8 & 7832.6 & 7030.2 & 61.4 & 741.0 & 0.947 & 0.638 \\
\hline Detmann et al. (2010a) & 203.1 & 87.0 & 55.7 & 3840.9 & 3103.6 & 26.6 & 718.7 & 0.947 & 0.776 \\
\hline
\end{tabular}

MPE - mean prediction error; MSPE - mean square of prediction error; SB - squared bias; SDSD - difference in the magnitude of fluctuation between predicted and observed values; LCS - the lack of positive correlation between predicted and observed values weighted by the standard deviations; $r$ - Pearson's linear correlation; CCC - concordance correlation coefficient. 
cause distortions in the estimates of truly digestible EE from the subtraction of a constant (Detmann et al., 2006b; 2008a). Thus, the assumption of proportionality between the truly digested and undigested materials would lead to some compensation among feed sources with different contents of EE. Such argument seems to support the greater accuracy observed for the sub-model presented by Detmann et al. (2010a), which is based on a multiplicative factor (Table 3; Figure 1).

Similarly to the results found for adEE, the sub-model designed for the prediction of the adNFC proposed by Detmann et al. (2010a) also presented lower MSPE, whose reduction was attributed almost exclusively to the lower bias of the estimates. Thus, both models seemed to be equally precise, but lower accuracy was verified in the submodel adopted by the NRC (2001) (Table 3; Figure 2).

Both sub-models built for the prediction of the adNFC are based on the concept of nutritional entity (Weiss et al., 1992;
Detmann et al., 2006a), presenting similar true digestibility coefficients (Detmann et al., 2006a). This indicates that the sub-models produce similar estimates with regard to the truly digestible NFC (Detmann et al., 2006a; 2008a). This way, the discrepancy between the sub-models must be attributed exclusively to differences in the estimates of the metabolic fecal fraction (Detmann et al., 2008a).

The metabolic fecal fraction of the NFC implicitly used in the sub-model adopted by the NRC (2001) was based on average data of fecal composition evaluated in cattle and sheep in non-tropical conditions (Weiss et al., 1992). However, the dimension of the metabolic fecal fraction is directly affected by the flow of nutrients towards the terminal part of the hind gut, which implies alterations in the cecal microbial activity, and by the level of fibrous compounds in the diet; such conditions are noticeably divergent among animals fed under tropical and nontropical conditions (Detmann et al., 2008a).
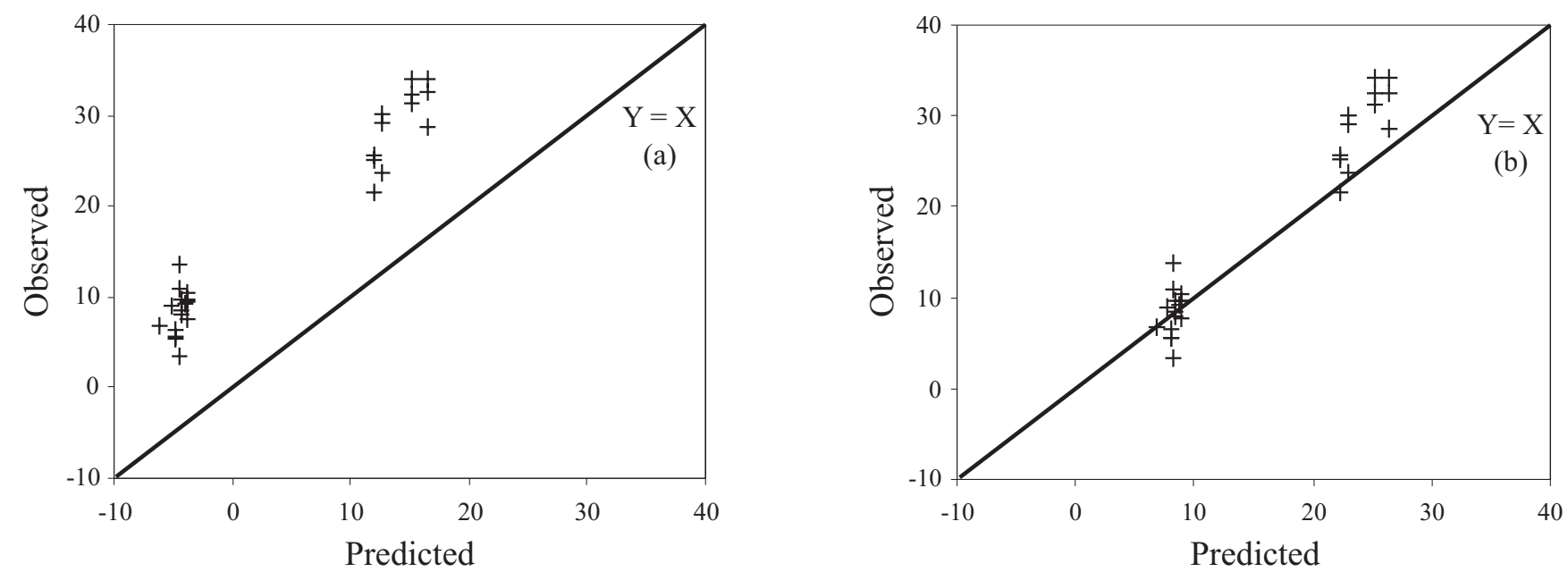

Figure 1 - Relationship between predicted and observed values of the diet content ( $\mathrm{g} / \mathrm{kg}$ dry matter) of the apparently digestible ether extract [NRC (2001), a; Detmann et al. (2010a), b].
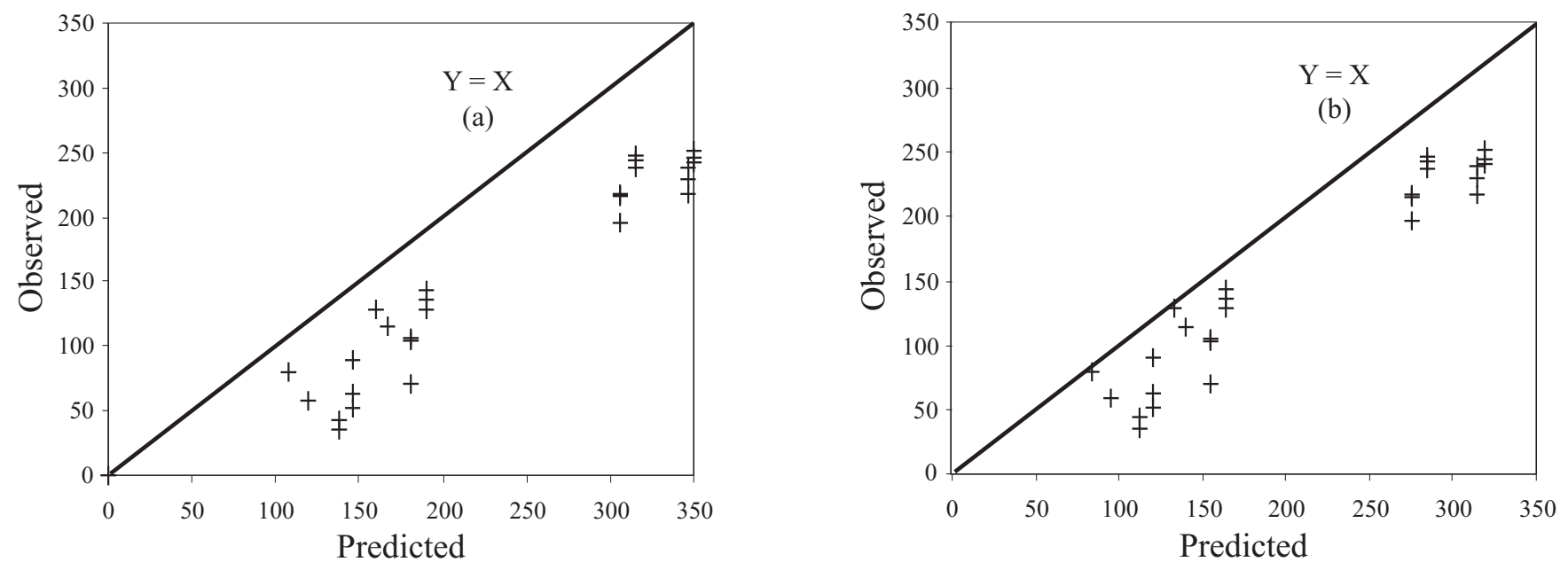

Figure 2 - Relationship between predicted and observed values of the diet content ( $\mathrm{g} / \mathrm{kg}$ dry matter) of apparently digestible non-fibrous carbohydrates [NRC (2001), a; Detmann et al. (2010a), b]. 
Therefore, the greater efficiency of the sub-model proposed by Detmann et al. (2010a) for the prediction of the adNFC results from the greater accuracy of the estimate of metabolic fecal fraction. The more exact estimates of metabolic fecal fractions can complementally contribute to the accuracy of the other apparently digestible fractions (adEE and adCP).

Due to the great number of sub-models evaluated for the estimate of the adCP, which resulted from the combination of different approaches and methods from the fundaments reported by Detmann et al. (2010a), the descriptive statistics of the relation between predicted and observed values (Table 4) were interpreted in a multivariate way by hierarchical clustering (Figure 3 ).

The multivariate analysis evinced the formation of four distinct groups: (1) single-compartment sub-model reported by Detmann et al. (2010a); (2) two-compartment submodels, considering all the digestibility coefficients of the pdCWCP and with estimation of the UNDIP by chemical approach; (3) two-compartmental sub-models, considering all the digestibility coefficients of the pdCWCP and with estimation of the UNDIP by in situ procedure; and (4) submodel adopted by the NRC (2001) (Figure 3).

From all the groups formed, greater discrepancy was observed for the single-compartment sub-model (Figure 3). Although it produced exact results, with low mean prediction error and, consequently, low $\mathrm{SB}$, this submodel differed from the others mainly by deficiency in the simulation of the magnitude of the differences of observed values around the sample mean (high value of component SDSD; Table 3).

The theoretical support for the utilization of the singlecompartment concept presented in equation (12) assumes the CP of the feed/diet as a homogenous nutritional entity (Detmann et al., 2008a). This implies that every fraction of the CP has similar and homogeneous utilization

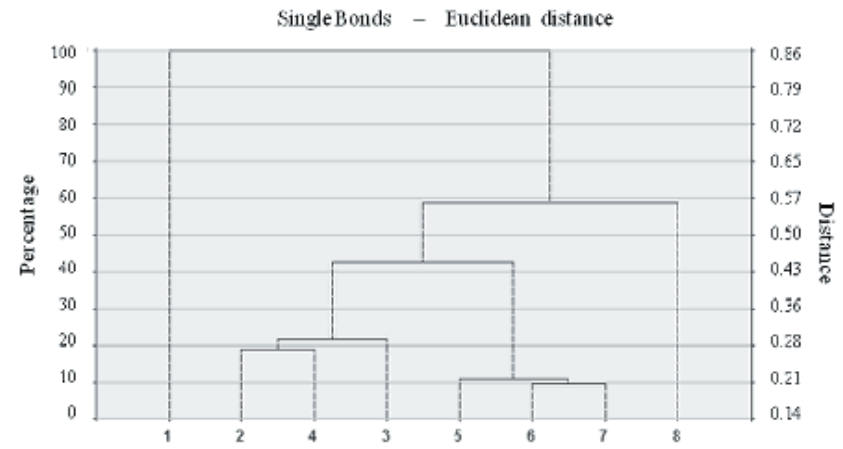

Figure 3 - Hierarchical clustering for the estimates of the diet content of apparently digestible crude protein [Detmann et al. (2010a): 1, S; 2, T/L/C; 3, T/G/C; 4, T/A/C; 5, T/L/I; 6, T/G/I; 7, T/A/I; NRC (2001), 8] (S and T, single-compartment and two-compartment models; L, $\mathrm{G}$ and $\mathrm{A}$, digestibility coefficients of the pdCWCP for lactating cows, growing and finishing cattle and their average, respectively; $\mathrm{C}$ and I, estimates of the UNDIP obtained by chemical approach or in situ procedure).

in the gastrointestinal tract. However, under tropical conditions, large influence is observed on the utilization of the nitrogenous compounds due to their association or non-association with the plant cell wall. This implies differentiation as for the rate and extension of the microbial action (Henriques et al., 2007; Detmann et al., 2008b) and attributes two-compartmental characteristics to the process of utilization of $\mathrm{CP}$ in the gastrointestinal tract.

This pattern corroborates the results obtained by Detmann et al. (2008b) and Magalhães et al. (2010), who observed that the single-compartment sub-model estimates the adCP with less efficiency under tropical conditions in comparison with the interpretation of the digestive process of the $\mathrm{CP}$ in the two-compartmental form.

The utilization of the different estimates of digestibility coefficient of the pdCWCP did not result in dissimilarity at the application of the two-compartment concept proposed

Table 4 - Means ( $\mathrm{g} / \mathrm{kg}$ dry matter) and descriptive statistics of the relation between observed and predicted values of the diet contents of apparently digestible crude protein

\begin{tabular}{|c|c|c|c|c|c|c|c|c|c|}
\hline Model & Mean & $\mathrm{s}$ & MPE & MSPE & $\mathrm{SB}$ & SDSD & $\mathrm{LCS}$ & r & $\mathrm{CCC}$ \\
\hline Observed & 43.8 & 33.9 & - & - & - & - & - & - & - \\
\hline NRC (2001) & 37.4 & 28.1 & -6.4 & 125.5 & 41.2 & 31.9 & 52.3 & 0.971 & 0.935 \\
\hline \multicolumn{10}{|c|}{ Detmann et al. (2010a) } \\
\hline $\mathrm{S}$ & 41.2 & 21.0 & -2.6 & 205.2 & 7.2 & 159.7 & 38.3 & 0.972 & 0.867 \\
\hline $\mathrm{T} / \mathrm{L} / \mathrm{C}$ & 48.1 & 24.4 & 4.2 & 161.1 & 18.2 & 87.6 & 55.2 & 0.965 & 0.905 \\
\hline $\mathrm{T} / \mathrm{G} / \mathrm{C}$ & 50.7 & 24.9 & 6.8 & 176.6 & 47.5 & 77.7 & 51.3 & 0.968 & 0.900 \\
\hline $\mathrm{T} / \mathrm{A} / \mathrm{C}$ & 49.5 & 24.7 & 5.6 & 167.6 & 32.0 & 82.5 & 52.9 & 0.967 & 0.903 \\
\hline $\mathrm{T} / \mathrm{L} / \mathrm{I}$ & 44.3 & 24.9 & 0.4 & 130.3 & 0.2 & 78.2 & 51.8 & 0.968 & 0.923 \\
\hline $\mathrm{T} / \mathrm{G} / \mathrm{I}$ & 45.9 & 25.6 & 2.0 & 118.8 & 4.3 & 66.6 & 47.7 & 0.971 & 0.932 \\
\hline $\mathrm{T} / \mathrm{A} / \mathrm{I}$ & 45.2 & 25.2 & 1.3 & 123.7 & 1.7 & 72.4 & 49.4 & 0.970 & 0.928 \\
\hline
\end{tabular}

MPE - mean prediction error; MSPE - mean square of prediction error; SB - squared bias; SDSD - difference in the magnitude of fluctuation between predicted and observed values LCS - the lack of positive correlation between predicted and observed values weighted by the standard deviations; $r$ - Pearson's linear correlation; CCC - concordance correlation coefficient. 
by Detmann et al. (2008b; 2010a) (Table 4; Figure 3). This is probably due to the fact that the pdCWCP represented a small fraction of the total CP (Table 1), causing the alterations in its digestibility coefficients to be of low magnitude concerning the total content of adCP.

On the other hand, dissimilarity at the utilization of the two-compartment concept proposed by Detmann et al. (2008b; 2010a) was observed when the estimates of UNDIP were obtained by chemical approach or in situ procedure (Figure 3). In this case, the utilization of in situ procedure promoted more exact estimates of adCP, presenting the lowest biases among all the sub-models assessed (Table 3).

The chemical approach of the UNDIP via ADIP presents some limitations because the UNDIP constitutes a biological concept with high variability (Detmann et al., 2010a; 2010b). Therefore, this approach must be utilized with caution, and it is preferable, when feasible, that the estimate of the UNDIP be obtained by biological method, i.e., through the evaluation of the residual CP of the iNDF estimated by long-term in situ procedures, followed by treatment of the sample with neutral detergent fiber for the removal of microbial debris (Clipes et al., 2010a; Detmann et al., 2010b).

The sub-model utilized by the NRC (2001) provided results with accuracy similar to that observed for the two-compartment sub-models considering the chemical approach for the UNDIP (Table 4; Figure 4). This behavior can be attributed to the fact that both approaches are based on the utilization of ADIP to predict the protein degradation (Equations 4, 5 and 17). However, the main element of dissimilarity for the sub-model proposed by the NRC (2001) was its lower estimate of the LCS component, which attributed greater precision to it (Table 4). Such behavior may reflect the fact that the action of the ADIP is considered different concerning the utilization of the $\mathrm{CP}$ of forages and concentrates by the approach given by the
NRC (2001), whereas Detmann et al. (2010a; 2010b) did not consider such differentiation in their approach.

The clustering analysis based on the descriptive statistics for the relation between predicted and observed values for the dNDF (Table 5) demonstrated the similarity for most sub-models assessed, except for the variants based on the proposal of Detmann et al. (2010a), in which in situ estimation procedure was utilized for the pdNDF associated to the digestibility coefficients of the pdNDF for lactating cows and average value for the two animal categories (Figure 5). For both cases, the highest biases were verified, among all the sub-models assessed, with underestimation of the dNDF (Table 5, Figure 6).

The meta-analytical derivation of the digestibility coefficients of the pdNDF utilized in the sub-model proposed by Detmann et al. (2010a) was based on the estimate of the pdNDF by in situ incubation procedures (Detmann et al., 2007). In this study, growing cattle were utilized, which seems to support the better prediction efficiency with the in situ estimation when digestibility coefficient for growing cattle was used (Table 5; Figure 6). The substitution by the digestibility coefficient applied for lactating cows $(0.67)$ and by the average of both categories (0.76) underestimated the dNDF, once they are lower than the digestibility coefficient applied to growing cattle (0.84).

This way, the sub-model based on the biological estimation of the pdNDF and on the utilization of the digestibility coefficient suggested for growing cattle must be assumed as a reference for comparison of the other sub-models.

Regardless of the digestibility coefficient adopted, the utilization of chemical approach for the estimation of the pdNDF generated results similar to the sub-model adopted by the NRC (2001) and to the utilization of in situ procedure with the digestibility coefficient for growing cattle proposed by Detmann et al. (2010a) (Figure 6).

Table 5 - Means ( $\mathrm{g} / \mathrm{kg}$ dry matter) and descriptive statistics of the relation between observed and predicted values of the diet contents of digestible neutral detergent fiber

\begin{tabular}{|c|c|c|c|c|c|c|c|c|c|}
\hline Model & Mean & $\mathrm{s}$ & MPE & MSPE & SB & SDSD & LCS & $\mathrm{r}$ & $\mathrm{CCC}$ \\
\hline Observed & 335.9 & 80.1 & - & - & - & - & - & - & - \\
\hline NRC (2001) & 307.2 & 44.7 & -28.7 & 3655.1 & 825.3 & 1202.6 & 1627.1 & 0.764 & 0.593 \\
\hline \multicolumn{10}{|c|}{ Detmann et al. (2010a) } \\
\hline $\mathrm{L} / \mathrm{C}$ & 301.6 & 46.2 & -34.3 & 3999.4 & 1177.7 & 1108.5 & 1713.1 & 0.760 & 0.578 \\
\hline $\mathrm{G} / \mathrm{C}$ & 378.1 & 57.9 & 42.2 & 4403.9 & 1780.8 & 473.1 & 2150.0 & 0.759 & 0.610 \\
\hline $\mathrm{A} / \mathrm{C}$ & 342.1 & 52.4 & 6.1 & 2720.4 & 38.0 & 739.3 & 1943.1 & 0.760 & 0.691 \\
\hline $\mathrm{A} / \mathrm{I}$ & 270.5 & 35.3 & -65.4 & 7451.2 & 4287.9 & 1934.9 & 1228.2 & 0.774 & 0.366 \\
\hline
\end{tabular}

MPE - mean prediction error; MSPE - mean square of prediction error; SB - squared bias; SDSD - difference in the magnitude of fluctuation between predicted and observed values; LCS - the lack of positive correlation between predicted and observed values weighted by the standard deviations; $r$ - Pearson's linear correlation; CCC - concordance correlation coefficient.

L, G and A - digestibility coefficients of the pdNDF digestibility for lactating cows, growing and finishing cattle and their average, respectively; C and I - estimates of the pdNDF obtained by chemical approach or in situ procedure. 

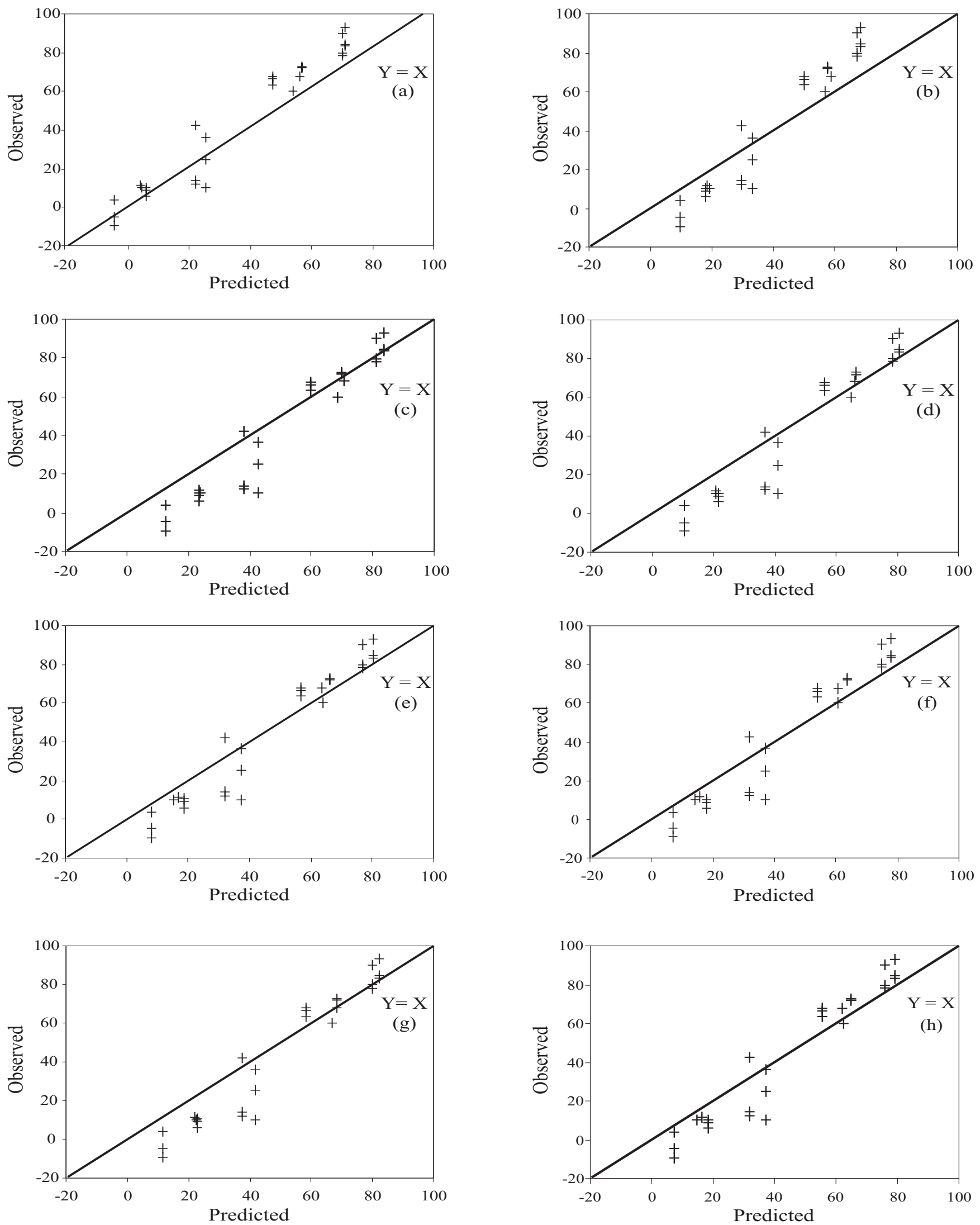

Figure 4 - Relationship between predicted and observed values of the diet content ( $\mathrm{g} / \mathrm{kg}$ dry matter) of apparently digestible crude protein [NRC (2001), a; Detmann et al. (2010a): b, S; c, T/G/C; d, T/L/C; e, T/G/I; f, T/L/I; g, T/A/C; h, T/A/I] (S and T, singlecompartment and two-compartment models; L, G and A, digestibility coefficients of the pdCWCP for lactating cows, growing and finishing cattle and their average, respectively; $\mathrm{C}$ and I, estimates of the UNDIP obtained by chemical approach or in situ procedure). 
Both in the sub-model adopted by the NRC (2001) (Equation 6) and in the sub-model with chemical approach suggested by Detmann et al. (2010a) (Equation 11), the procedures of estimation of the pdNDF fraction and its digestibility coefficient were conducted independently (Weiss et al., 1992; Detmann et al., 2004; 2007). This way, opposite biases could be verified in each one of the processes, making the final sub-model, given by the combination of these two characteristics, present bias similar to the submodel assumed as reference previously described.

According to Detmann et al. (2007), the utilization of gravimetric estimates of the lignin content, as utilized in the sub-models with chemical approach, may not provide exact estimates of the pdNDF and iNDF fractions, once several environmental effects have remarkable influence on the chemical structure and on the spatial arrangement of the lignin complex in the cell wall. Therefore, a simple gravimetric estimate would not allow an accurate estimation of the true inhibitory action of lignin on the fibrous carbohydrates of feeds.

From the results presented, the TDN contents (Table 6) were estimated according to the fundaments exposed by Detmann et al. (2010a), by utilizing approaches for the adCP and dNDF fractions in which both methods (chemical and in situ) were considered for the estimation of the UNDIP and pdFDN. Due to the absence of influence from the different digestibility coefficients of pdCWCP on adCP (Table 4; Figure 4), only the coefficient applied to growing cattle was assessed, for it propitiated the best dNDF estimate considering the in situ evaluation of pdNDF (Table 5) and converges to the animal category evaluated in this study.

In addition, the prediction of the iNDF fraction through chemical methods becomes dependent on the association between the estimate of the lignin content and the extent of the degradation of the insoluble fiber. According to Gomes et al. (2011), none of the different methods

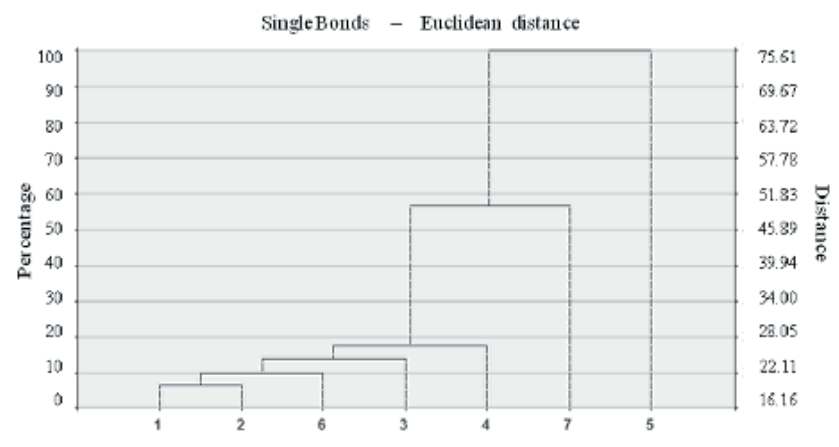

Figure 5 - Hierarchical clustering for estimates of the diet content of digestible neutral detergent fiber [NRC (2001), 1; Detmann et al. (2010a): 2, L/C; 3, G/C; 4, A/C; 5, L/I; 6, G/I; 7, A/I] (L, G and A, digestibility coefficients of the pdNDF for lactating cows, growing and finishing cattle and their average, respectively; $\mathrm{C}$ and I, estimates of the pdNDF obtained by chemical approach or in situ procedure).

employed at the evaluation of lignin fully meets the nutritional expectation, with significant differences in the results obtained in laboratories for all the methods applied. Stronger correlations between lignin contents and extent of the rumen degradation of the NDF have been obtained by methods distinct from the one adopted by the NRC (2001) and suggested by Detmann et al. (2010a) (Traxler et al., 1998; Clipes et al., 2010b; Gomes et al., 2011). This seems to indicate that limitations intrinsic of the lignin content estimated by the method of acid hydrolysis may reduce the accuracy of estimates of the pdNDF and iNDF fractions by chemical approach.

Thus, the obtainment of estimates of iNDF and pdNDF by means of biological method (in situ procedure) must be considered, essentially, a more exact estimation method for accessing the dNDF contents.

Considering accuracy and precision simultaneously, which are actually pondered by the CCC estimate, the best estimates of the TDN content were obtained by utilizing

Table 6 - Means ( $\mathrm{g} / \mathrm{kg}$ dry matter) and descriptive statistics of the relation between observed and predicted values of the diet contents of total digestible nutrients

\begin{tabular}{lccccccccc}
\hline Model & Mean & $\mathrm{s}$ & MPE & MSPE & SB & SDSD & LCS & r & CCC \\
\hline Observed & 566.0 & 95.4 & - & - & - & - & - & - & - \\
NRC(2001) & 583.7 & 82.7 & 17.7 & 5906.7 & 315.8 & 155.7 & 5435.2 & 0.643 & 0.624 \\
Detmann et al. (2010a) & & & & & & & & & \\
PC/FC & 666.1 & 62.5 & 100.1 & 15173.1 & 10022.8 & 1043.0 & 4107.1 & 0.643 & 0.333 \\
PI/FC & 661.3 & 62.6 & 95.3 & 14304.7 & 9085.4 & 1036.7 & 4182.5 & 0.637 & 0.344 \\
PC/FI & 586.9 & 109.4 & 20.9 & 5116.6 & 437.5 & 187.7 & 4490.4 & 0.777 & 0.754 \\
PI/FI & 582.1 & 109.2 & 16.1 & 4967.0 & 260.1 & 183.6 & 4523.3 & 0.775 & 0.758 \\
\hline
\end{tabular}

MPE - mean prediction error; MSPE - mean square of prediction error; SB - squared bias; SDSD - difference in the magnitude of fluctuation between predicted and observed values; LCS - the lack of positive correlation between predicted and observed values weighted by the standard deviations; $r$ - Pearson's linear correlation; CCC - concordance correlation coefficient.

${ }^{1}$ PC and PI, UNDIP estimated by chemical approach or by in situ procedure; FC, FI and pdNDF estimated by chemical approach or in situ procedure. 

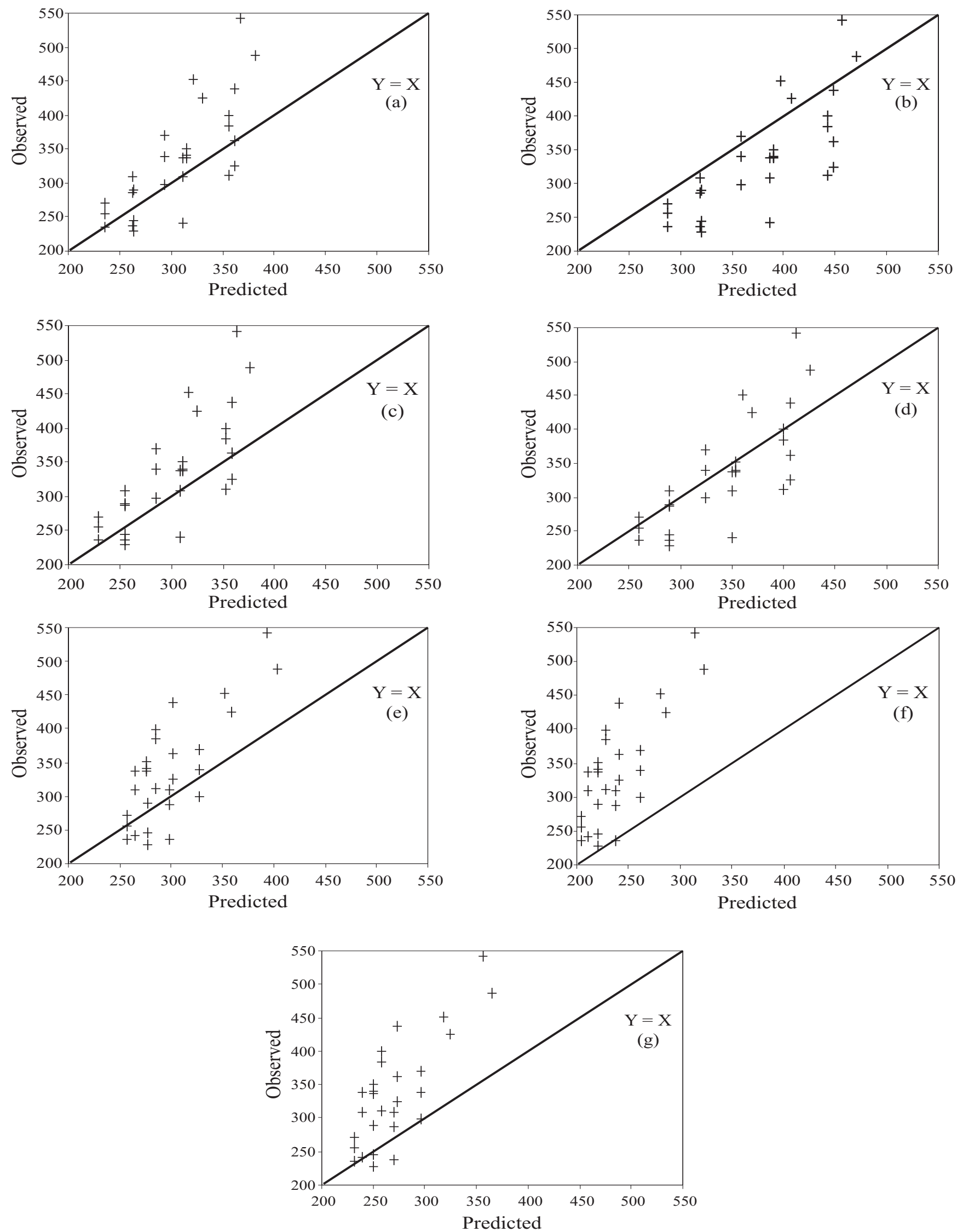

Figure 6 - Relation between predicted and observed values of the diet content ( $\mathrm{g} / \mathrm{kg}$ dry matter) of digestible neutral detergent fiber [NRC (2001), a; Detmann et al. (2010a): b, G/C; c, L/C; d, A/C; e, G/I; f, L/I; g, A/I] (L, G and A, digestibility coefficients of the pdNDF for lactating cows, growing and finishing cattle and their average, respectively; $\mathrm{C}$ and I, estimates of the pdNDF obtained by chemical approach or in situ procedure). 
the in situ estimation procedure of pdNDF, regardless of the approach adopted for adCP. On the other hand, the utilization of chemical approach for pdNDF decreased the accuracy and precision of the estimates, presenting, additionally, little influence from the method of UNDIP estimation (Table 6; Figures 7 and 8).

Firstly, this pattern corroborates the fact that the small loss of accuracy observed when replacing the in situ procedures by chemical approach for estimation of the UNDIP (Table 4) does not exert significant influence on the TDN estimates (Figure 7). On the other hand, once choosing for the in situ procedure for estimation of the pdNDF, the evaluation of the UNIDP via in situ procedure becomes natural, once it consists of the $\mathrm{CP}$ present in the
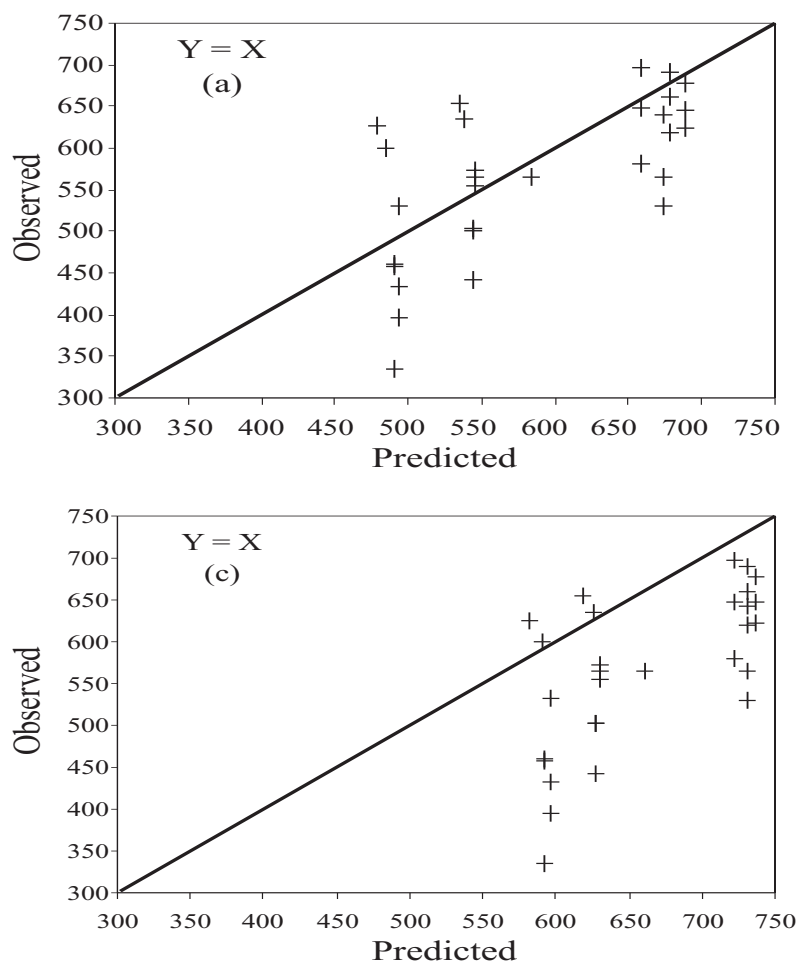

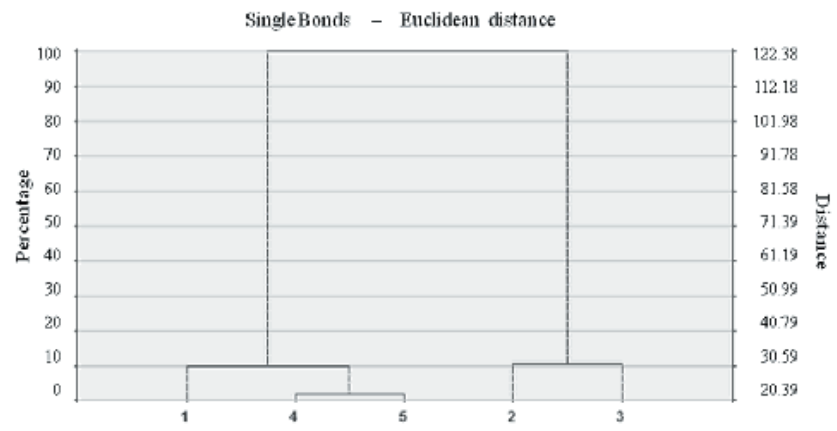

Figure 7 - Hierarchical clustering for the estimates of the diet content of total digestible nutrients [NRC (2001), 1; Detmann et al. (2010a): 2, PC/FC; 3, PI/FC; 4, PC/FI; $5, \mathrm{PI} / \mathrm{FI}$ ( $\mathrm{PC}$ and PI, UNDIP estimated by chemical approach or in situ procedure; FC and FI, pdNDF estimated by chemical approach or in situ procedure).
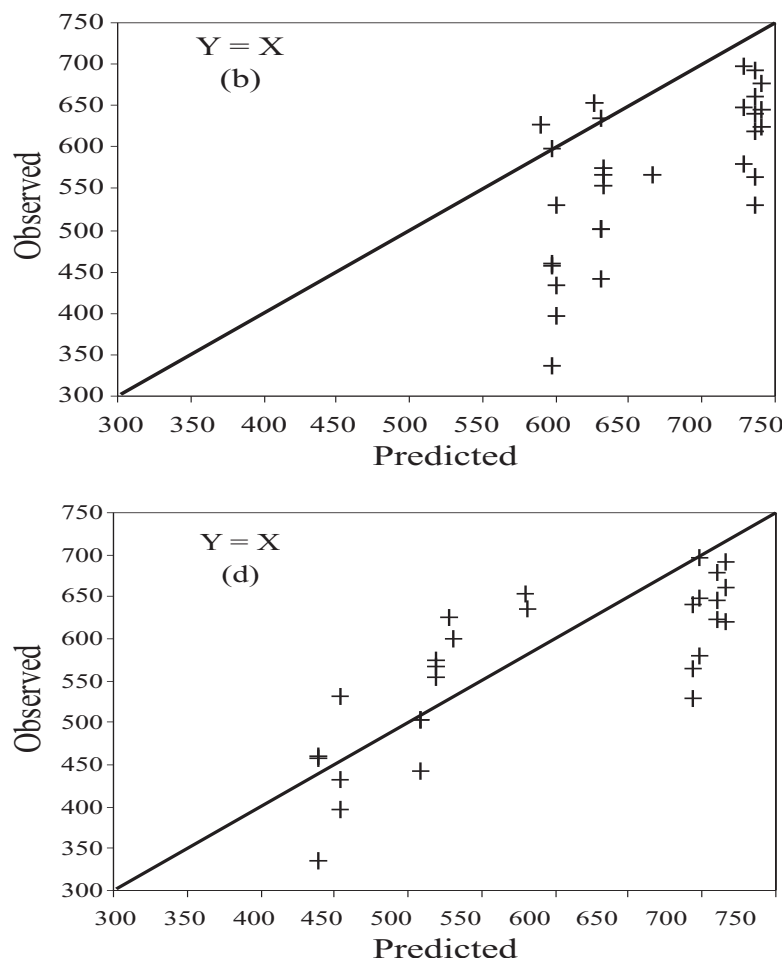

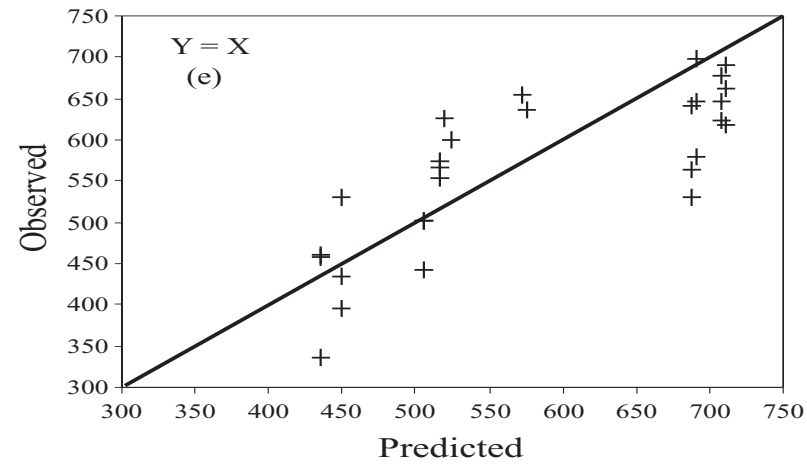

Figure 8 - Relation between predicted and observed values of the diet content ( $\mathrm{g} / \mathrm{kg}$ dry matter) of total digestible nutrients [NRC (2001), a; Detmann et al. (2010a): b, PC/FC; c, PI/FC; d, PC/FI; e, PI/FI] (PC and PI, UNDIP estimated by chemical approach or in situ procedure, respectively.; FC and FI, pdNDF estimated by chemical approach or in situ procedure, respectively. 
iNDF, which would only require one additional simple and quick laboratory analysis.

The lower precision and accuracy of the TDN contents obtained from the utilization of chemical approach for the pdNDF in the sub-model adopted by Detmann et al. (2010a) seems to be a result of some incompatibility between the estimates of the digestibility coefficient of the pdNDF and the lignin constraint factor (Equation 11). As stressed before, such parameters were estimated independently (Detmann et al., 2004; 2007), which could cause such limitations in the estimation process. These arguments are reinforced by the variation verified in the estimates of the SDSD component for the dNDF when different estimates of the digestibility coefficient of pdNDF are utilized (Table 5). Although the sub-model applied to the estimation of the dNDF adopted by the NRC (2001) has a basis similar to the chemical approach suggested by Detmann et al. (2010a), the latter conferred greater precision to the estimates of TDN (Table 6).

It must be emphasized that the diets evaluated in this study can be considered of medium to low quality (Table 2), which can contribute to the lower prediction efficiency for the chemical approach of the pdNDF suggested by Detmann et al. (2008a; 2010a). Contrarily to the observed in this study, Detmann et al. (2008a) and Magalhães et al. (2010) evaluated diets with quality superior to the ones herein assessed and verified that the chemical approach adopted by the NRC (2001) produced results with lower precision (lower estimate of the SDSD component) in comparison with the chemical approach suggested by Detmann et al. (2010a).

This demonstrates that the high natural variability of the interaction between carbohydrates and phenolic compounds in the insoluble fibrous fraction still represents a constraint to the predictive process of the digestible fraction of the NDF by chemical approach, thus requiring the development of models from a database of wider amplitude in terms of dietary quality and composition and/or alterations in the analytical techniques utilized for the quantification of the lignin contents.

\section{Conclusions}

The estimates of the content of total digestible nutrients were more efficiently produced from the sub-models proposed by Detmann et al. (2010a) when biological procedures were considered for the estimation of the protein undegradable fraction and of the potentially degradable fraction of neutral detergent fiber.

\section{References}

CASALI, A.O.; DETMANN, E.; VALADARES FILHO, S.C. et al. Influência do tempo de incubação e do tamanho de partículas sobre os teores de compostos indigestíveis em alimentos e fezes bovinas obtidos por procedimentos in situ. Revista Brasileira de Zootecnia, v.37, p.335-342, 2008

CLIPES, R.C.; SILVA, J.F.C.; DETMANN, E. et al. Proteína insolúvel em detergente ácido como estimador da fração protéica não degradável no rúmen de forragens tropicais. Revista Brasileira de Saúde e Produção Animal, v.11, p.463-473, 2010a.

CLIPES, R.C.; SILVA, J.F.C.; DETMANN, E. et al. Predição da fração indegradável da fibra em detergente neutro em forragens tropicais a partir da concentração de lignina. Revista Brasileira de Saúde e Produção Animal, v.11, p.999-1011, 2010b.

CONRAD, H.R.; WEISS, W.P.; ODWONGO, W.O. et al. Estimating net energy lactation from components of cell solubles and cell walls. Journal of Dairy Science, v.67, p.427-436, 1984.

CRUZ, C.D.; REGAZZI, A.J. Modelos biométricos aplicados ao melhoramento genético. 2 ed. Viçosa, MG: Editora UFV, 2002. 390p.

DETMANN, E. Fibra na nutrição de novilhas leiteiras. In: PEREIRA, E.S.; PIMENTEL, P.G.; QUEIROZ; A.C. et al. (Eds.). Novilhas leiteiras. Fortaleza: Graphiti Gráfica e Editora Ltda, 2010. p.253-302.

DETMANN, E.; VALADARES FILHO, S.C. On the estimation of non-fibrous carbohydrates in feeds and diets. Arquivo Brasileiro de Medicina Veterinária e Zootecnia, v.62, p.980-984, 2010.

DETMANN, E.; ZERVOUDAKIS, J.T.; CABRAL, L.S. et al. Validação de equações preditivas da fração indigestível da fibra em detergente neutro em gramíneas tropicais. Revista Brasileira de Zootecnia, v.33, p.1866-1875, 2004.

DETMANN, E.; PINA, D.S.; VALADARES FILHO, S.C. et al. Estimação da digestibilidade dos carboidratos não-fibrosos em bovinos utilizando-se o conceito de entidade nutricional em condições brasileiras. Revista Brasileira de Zootecnia, v.35, p.1479-1486, 2006a.

DETMANN, E.; VALADARES FILHO, S.C.; PINA, D.S. et al. Estimação da digestibilidade do extrato etéreo em ruminantes a partir dos teores dietéticos: desenvolvimento de um modelo para condições brasileiras. Revista Brasileira de Zootecnia, v.35, p.1469-1478, 2006b.

DETMANN, E.; VALADARES FILHO, S.C.; HENRIQUES, L.T. et al. Reparametrização do modelo baseado na lei de superficie para predição da fração digestível da fibra em detergente neutro em condições brasileiras. Revista Brasileira de Zootecnia, v.36, p.155-164, 2007.

DETMANN E.; VALADARES FILHO, S.C.; PINA, D.S. et al. Predition of the energy value of cattle diets based on the chemical composition of the feeds under tropical conditions. Animal Feed Science and Technology, v.143, p.127-147, 2008a.

DETMANN, E.; MAGALHÃES, K.A.; VALADARES FILHO, S.C. et al. Desenvolvimento de um sub-modelo bicompartimental para estimação da fração digestível da proteína bruta em bovinos a partir da composição química dos alimentos. Revista Brasileira de Zootecnia, v.37, p.2215-2221, 2008b.

DETMANN, E.; VALADARES FILHO, S.C.; PAULINO, M.F. Predição do valor energético de dietas para bovinos a partir da composição química dos alimentos. In: VALADARES FILHO, S.C.; MARCONDES, M.I.; CHIZZOTTI, M.L. et al. (Eds.). Exigências nutricionais de zebuínos puros e cruzados BRCORTE. 2.ed. Viçosa, MG: DZO-UFV, 2010a. p.47-64.

DETMANN, E.; SILVA, J.F.C.; CLIPES, R.C. et al. Estimação por aproximação química dos teores de proteína indegradável insolúvel em detergente neutro em forragens tropicais. Arquivo Brasileiro de Medicina Veterinária e Zootecnia, v.62, p.742-746, 2010b.

GOMES, D.I.; DETMANN, E.; VALADARES FILHO, S.C. et al. Evaluation of lignin contents in tropical forages using different analytical methods and their correlations with degradation of insoluble fiber. Animal Feed Science and Technology, v.168, p.206-222, 2011. 
HENRIQUES L.T.; DETMANN, E.; QUEIROZ, A.C. et al. Frações dos compostos nitrogenados asociados à parede celular em forragens tropicais. Arquivo Brasileiro de Medicina Veterinária e Zootecnia, v.59, p.258-263, 2007

KOBAYASHI, K.; SALAM, M.U. Comparing simulated and measured values using mean squared deviation and its components. Agronomy Journal, v.92, p.345-352, 2000.

LICITRA, G.; HERNANDEZ, T.M.; Van SOEST, P.J. Standardization of procedures for nitrogen fractionation of ruminant feeds. Animal Feed Science and Technology, v.57, p.347-358, 1996.

LUCAS, H.L.; SMART, W.W.G. Chemical composition and the digestibility of forages. In: PASTURE AND CROP IMPROVEMENT CONFERENCE, 16., 1959, Mississippi. Proceedings... Mississippi, 1959. p.23-26.

MAGALHÃES, K.A.; VALADARES FILHO, S.C.; DETMANN, E. et al. Evaluation of indirect methods to estimate the nutritional value of tropical feeds for ruminants. Animal Feed Science and Technology, v.155, p.44-54, 2010.

MERTENS, D.R. Gravimetric determination of amylase-treated neutral detergent fiber in feeds with refluxing in beakers or crucibles: collaborative study. Journal of AOAC International, v.85, p.1217-1240, 2002.

NATIONAL RESEARCH COUNCIL - NRC. Nutrient requirements of dairy cattle. 7.ed. Washington, D.C.: Academic Press, 2001. 381p.

SILVA, D.J.; QUEIROZ, A.C. Análise de alimentos. Métodos químicos e biológicos. 3.ed. Viçosa, MG: Editora UFV, 2002. 235p.

TEDESCHI, L.O. Assessment of the adequacy of mathematical models. Agricultural Systems, v.89, p.225-247, 2006.

TRAXLER, M.J.; FOX, D.G.;Van SOEST, P.J. et al. Predicting forage indigestible NDF from lignin concentration. Journal of Animal Science, v.76, p.1469-1480, 1998.

VALENTE, T.N.P. Utilização de tecidos na avaliação de compostos fibrosos e na degradação ruminal in situ de alimentos para ruminantes. 2010. 90f. Tese (Doutorado em Zootecnia) Universidade Federal de Viçosa, Viçosa, MG.

Van SOEST, P.J. Nutritional ecology of the ruminant. 2.ed. Ithaca: Cornell University Press. 1994. 476p.

WEISS, W.P.; CONRAD, H.R.; St.PIERRE, N.R. A theoreticallybased model for predicting total digestible nutrient values of forage and concentrates. Animal Feed Science and Technology, v.39, p.95-110, 1992. 